\title{
9. People and Partnership: An Australian Model for International Arts Exchanges - The Asialink Arts Program, 1990-2010
}

\begin{abstract}
Alison Carroll
'You could never have told me what it would be like.' Australian curator, Malaysia, 1993

'It was the hardest and the best thing I have ever done.'

Australian artist in residence, China, 1996

This essay outlines how Asialink Arts, a small program evolving in Melbourne from 1990, became the main arts exchange vehicle for Australian arts engagement with Asia over the next two decades. The program was based on the principle of 'people and partnership'.
\end{abstract}

The comments at the beginning of this essay from a curator and an artist always resonated for the Asialink Arts program. They relate to the crucial role of personal experience in a different culture, and how creative people respond to this. Opening up opportunities for Australian creative people in Asia and supporting their experience was the most important role of the arts program at Asialink over the period of this essay, 1990-2010. ${ }^{1}$ The program provided access to the variety and richness of the contemporary cultures of Asia by establishing links which artists and others could utilise and build on. It was based on the idea that artists need just a little help to take their creativity, passion and determination into new worlds, as well as on the concept of trusting them to be mature partners in this endeavour, with few checks and balances and, in reality, minimal support. This mission and focus remained consistent over time. It is remarkable, reading back over the Asialink files, how little the intention, structure and even the words changed over the period: providing opportunities, giving access, providing support and encouragement, leading to the creation of new works of meaning to the artists themselves and to their new audiences in the region. ${ }^{2}$

\footnotetext{
1 Asialink started in the late 1980s in Melbourne as a project of the Commission for the Future, with the aim of encouraging Australians to engage more closely with Asia. The early focus was on political and social issues. In 1991 the organisation became a centre at the University of Melbourne, where it remains. The Myer Foundation supported the wider Asialink program throughout this period. See www.asialink.unimelb.edu.au. 2 The first information sheet for the Artist in Residence program, written in 1991, states: 'The aim of the program is to enlarge the experience available to Australian artists in our own region, to enable a longer term involvement with the host country, and to encourage ongoing contacts between Australian and Asian artists.' None of these words - or intentions - changed over 20 years.
} 
At Asialink we realised that the easiest path to increasing knowledge of Asian culture and to encourage direct experience was through the contemporary world: the artist of today. The premise of 'exchange' was that artists were talking to each other and to audiences, across cultures, either in person or through their work. The program was clearly about Australians and Australian work going to Asia, rather than the reverse. The reasons were many: that everyone learns by being or having their work seen by others and that we Australians had been poor at promoting our own work in the region (and much better at importing Asian work to Australia as is evidenced, for example, in the number of exhibitions invited by our museums). Also, I (and the funding was predicated on this) thought our scarce Australian arts resources should be focused on Australian artists and art, and that if people in Asia wished to come to Australia, Asialink would help with advice but they had to provide the organisational and financial backing themselves. I saw the alternative as an aid argument and did not envisage the program in this way.

Australian artists responded to Asialink with enthusiasm and, in the first 20 years of operation, the program supported some 600 artists in residence and innumerable other artists, curators, performers and writers committed to engaging with Asia. Their experiences have provided a vital resource for Australia's future. ${ }^{3}$ It was not always easy. One of the satisfactions was in seeing artists return from an Asialink supported experience in Asia expressing not only their pride in the work they had done, but also their increased belief in their own ability to manage new and often difficult challenges.

A key element of the program, both for individuals and a variety of artist communities and institutions was the idea of partnership. As Carrillo Gantner and I have argued elsewhere:

The critical ingredients for international exchanges in the arts are people and partnerships. Together these generate the creative product. If real partnership among the parties on both sides is built from the beginning of an exchange program, surprising results ensue. Partnerships are essential in this work so that everyone has a stake in the artistic outcome. Partnership means that new ideas and new works can be forged together, giving the greatest gift to all involved. Partnership also means that administration and costs can be shared, reducing one of the perceived barriers to engagement. Partnerships built on respect for each

\footnotetext{
3 Asialink has produced two publications listing the residencies: 35,000 Days in Asia and 45,000 Days in Asia; The Asialink Arts Residency Program in 2004 and 2007 respectively, listing all residents to those dates. An annual Newsletter, published since 1998, has listed each person travelling for the previous year, and these Newsletters continue, echoed in the Asialink website: www.asialink.unimelb.edu.au/ourwork. The Asialink Exhibition program has been documented in Alison Carroll \& Sarah Bond, Every 23 Days: 20 Years Touring Asia (Asialink, University of Melbourne, 2010). It lists the nearly 80 exhibitions toured, including curators, artists, venues and institutional partners.
} 
partner's creative and administrative contribution mean problems can be foreseen and overcome. In art as in life, this is the only way we can grow in a global world. ${ }^{4}$

Australia's relationship with Asia has changed over the nearly 25 years that Asialink Arts has been in existence. That relationship has benefited from increasing, if varied, degrees of government interest and engagement. From the focus on the region that developed under the federal Labor government of Paul Keating in the early 1990s, followed by a slowing interest in the ensuing decade, to the 2012 federal government's Asian Century white paper, ${ }^{5}$ Asia remains on the political horizon in a way that was not the case prior to 1990. Relationships changed - from the few 'true believers' of the early years to the much wider, more sophisticated and intertwined engagement gained in more recent times.

The arts play a paradoxical role in Australia's relationship with Asia. Despite being central to our wellbeing and how we see ourselves, able to cross cultural boundaries, and led by curious and brave individuals, the arts have, frequently, taken a back seat to business and politics in the minds of people who care about the relationship. Equally, for many Australians the arts of Asia were, and remain, intimidating, inscrutable and 'difficult'.

\section{Some History}

The first steps towards the establishment of the Asialink Arts Program were taken as a result of my realisation, while on holiday in Sri Lanka in the early 1980s, that I had never heard the names of the ancient cultural sites in that country - wonderful, elegant and extensive as they are-despite six years of formal art history training in Australia. This realisation inspired me to curate several exhibitions; one of the largest being East and West, which was held in 1985 at the Art Gallery of South Australia and addressed the interaction of Asian and European (and Australian) art. ${ }^{6}$ In working towards this exhibition, I was acutely aware of the paucity of published information on the visual art of the Asian region post 1900. I received a grant from the Visual Arts/Craft Board of the Australia Council for the Arts (VACB) to travel in South-East Asia, to explore ways of redressing this situation. ${ }^{7}$ Everyone there said the same thing:

\footnotetext{
4 Alison Carroll \& Carrillo Gantner, Finding a Place on the Asian Stage, Platform Paper 31 (Currency House, 2012), 12 .

5 Department of Prime Minister and Cabinet, Australia in the Asian Century, White Paper (Canberra, 2012). 6 Carroll, The State's Collections; East and West; The Meeting of Asian and European Art, Art Gallery of South Australia, 1985. The exhibition was curated by Alison Carroll, assisted by Dick Richards, Judith Thompson and Ron Radford.

7 Australia Council Travel Grant to South-East Asia (Thailand, Indonesia, Malaysia, Singapore, Laos, Vietnam, Philippines), taken in two trips in 1988 and 1990. The Australia Council for the Arts is the Australian Government's official arts advisory and funding body and is divided into several divisions. The Visual Arts/ Crafts Board was one of the key divisions at the time Asialink was establishing its Arts Program.
} 
they wanted to see more contemporary art, from 'elsewhere'-Australia, the world, anywhere. In response I developed Eight Views, an exhibition of contemporary Australian art, that toured in 1990-1991, under the umbrella of AETA (Australian Exhibitions Touring Agency), to five national galleries of South-East Asia. ${ }^{8}$ This project gave me practical experience in the methods of touring exhibitions internationally and a deeper understanding of the existing funding opportunities, the interest of audiences and the keenness of artists to take part in similar projects.

Asialink was in its early days when I approached it to support the ideas I envisaged as a follow-up to the Eight Views exhibition. With the agreement of Jenny McGregor (then project officer at Asialink, now CEO), I put together a program brief of exhibitions of Australian art and, after discussions with the Australia Council, the idea emerged of linking this to their existing program of artist residencies in Asia. We asked for support from both the Department of Foreign Affairs and Trade (DFAT), and the Council and, in February 1991, we received $\$ 30,000$ seed funding from DFAT. ${ }^{9}$ In May, the Council agreed to match the DFAT funds. ${ }^{10}$ Les Rowe, assistant secretary at DFAT, later told me that he was not expecting to hear from us again. Little did he know.

\section{The Program}

Over the next 20 years, the Asialink Arts Program continued to receive strong organisational, financial and collegiate support from DFAT, via the department

8 Carroll, Art from Australia; Eight Contemporary Views (Australian Exhibitions Touring Agency, 1990). The artists were Micky Allan, John Davis, Richard Dunn, Anne Ferran, Fiona Hall, Imants Tillers, Caroline Williams and John Young. The exhibition was a large project with significant support from the Department of Foreign Affairs and Trade, the Australia Council and Westpac Banking Corporation. It travelled to the national galleries of Thailand, Indonesia, the Philippines, Malaysia and Singapore.

9 Correspondence from Leslie Rowe, assistant secretary, Cultural Relations Branch, Department of Foreign Affairs and Trade, of 19 February 1991, included the welcome words: 'We have studied the proposal carefully and I am pleased to advise you that we are prepared to offer a contribution of $\$ 30,000$ as seeding funds to establish the project as outlined in your letter of 14 January 1991 to enable the project to get underway in the first half of 1991.'

10 Correspondence from Ian Were, program officer, Visual Arts/Craft Board of the Australia Council, of 22 November 1993 confirms new funding for the years 1994-1996, and includes the words: 'In making its decision the Visual Arts/Craft Board's (VACB) International Promotion Committee discussed the "Australian Art to Asia" project at length and wanted to congratulate Asialink and its visual arts coordinator, Alison Carroll on the success of the program over 1991-1993. Clearly Asialink has achieved much with the residency and exhibition programs, has gathered and exchanged information, and has been able to attract substantial support from a range of other agencies. The Committee was enthusiastic about the potential of the project to further develop and consolidate relationships through the Asian region, and has therefore agreed to a major commitment over the next three years, 1994 to 1996.' 
in Canberra ${ }^{11}$ and through its diplomatic posts in Asia. By 2010, the combined annual funding from DFAT and the Australia Council had increased from $\$ 120,000$ to $\$ 760,000 .^{12}$

While in some respects this was significant support for a small agency, it can also be regarded, conversely, as a tiny contribution to the running of the nation's main Asia-Australia arts program.

Asialink's early projects came to fruition on a wing and a prayer. I asked for practical assistance and support from people who I knew might be open to and interested in the possibility of working in Asia, such as Anne Kirker of Queensland Art Gallery (QAG) and Juliana Engberg, then a freelance curator. I also contacted those few organisations that, at the time, were expressing strong interest in Asia, such as QAG and the Royal Melbourne Institute of Technology (RMIT).

Kirker was the first to respond with an exhibition of Australian prints called $6 \times 6,{ }^{13}$ which toured to three venues in Thailand, including Khon Kaen in the north-east of the country. She wrote, 20 years later:

I am working now with Thai artist Prawat Laucharoen on a collaborative print installation project with artists at his loft space in New York. Mostly we are communicating by e-mail, unlike the very slow and travel-intensive way we achieved shows in the early 1990s.

With the $6 \times 6$ exhibition I worked closely with co-curator Somporn Rodboon, from Silpakorn University. She, like myself, had a special interest in printmaking. It was trial and error for us both with this show, although Ajarn Somporn had already organised international print

\footnotetext{
11 The key section within DFAT Canberra was the Cultural Relations Branch, led by Neil Manton at first and, at the end of my tenure, Anthony Taylor. Manton has outlined DFAT's history of sending contemporary Australian art to Asia in his book Cultural Relations: The Other Side of the Diplomatic Coin (Canberra: Homosapien Books, 2003), Chpt. 3. The majority of examples occurred over the period 1947-1970. Manton's experience, and support, was key to Asialink's early successful touring. The individuals within the Cultural Relations Branch were important people who had either worked in Asia or would in the future, and whose knowledge of Australian art and how it was viewed internationally was significant. Around this central culture node was the work of the 'FCIs' (foundations, councils and institutes) or bilateral agencies, like the AustraliaIndonesia Institute, the Australia-Japan Foundation and so on, financially supported by DFAT, and all with culture forming part of their agenda of encouraging 'people-to-people' relationships. Again, knowledgeable arts professionals were included on their boards, co-editor of this publication Caroline Turner (then deputy director of the Queensland Art Gallery), being one of them, and they added to the pool of expertise.

12 As one measure of 'success', Asialink Arts became the largest recipient of funding from the Australia Council for the Arts. This observation was made by Australia Council staff member Andrew Donovan to the writer in 2010 and excludes the clients of the Major Performing Arts Board of the Council, which supports the main theatre companies in the country. Of course the Australia Council's support is only one part of a complex matrix of arts funding in Australia, and many other organisations would receive more substantial overall support through this combination.

$136 \times 6$ : A Selection of Contemporary Australian Prints (Asialink, University of Melbourne, in association with the Queensland Art Gallery, 1992), curator Anne Kirker; artists Ray Arnold, Diane Mantzaris, Milan Milojevic, Ann Newmarch, Graeme Pebbles and Judy Watson.
} 
shows for the Gallery at Silpakorn. It was great that curator Roger Butler conducted the first professional practice workshop in Thailand at the time of $6 \times 6$. We framed the works in Thailand and sent them on the road after the stint in Bangkok. I never forget walking with Robert Pound from the Australian Embassy and the Khon Kaen University gentleman in charge of organising the event there along a long veranda to get to the exhibition area, with the doors wide open to a room inside and a draped cadaver waiting for medical students to prod around. ${ }^{14}$

Progress involved establishing touring venues and hosts for residencies in Asia. I approached people in Asia who I knew might be willing to assist the program, particularly those that I met on the Australia Council research trip of the late 1980s and the subsequent touring of the Eight Views exhibition, as well as the diplomatic posts.

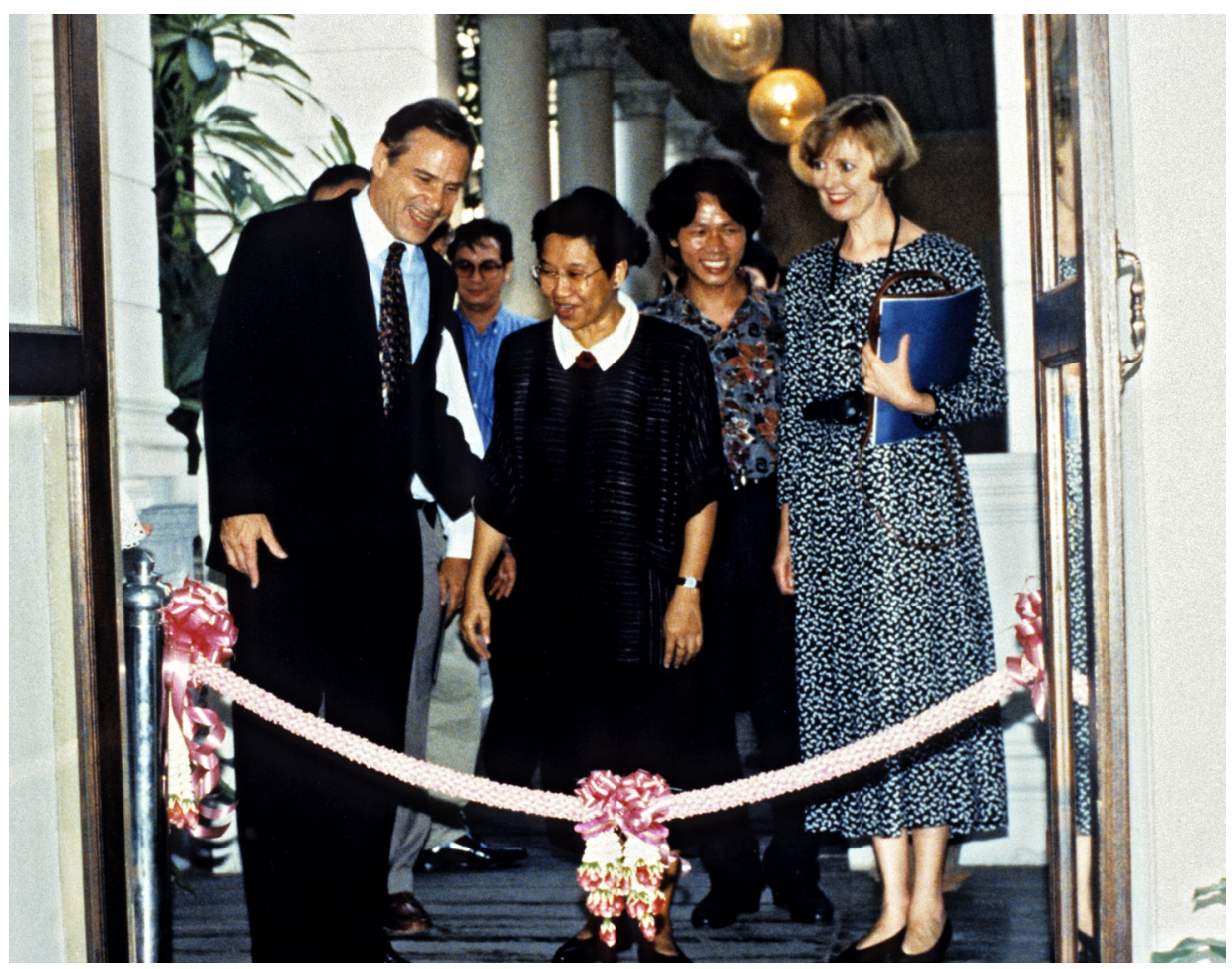

Opening ceremony, '6 x 6; A Selection of Contemporary Australian Prints', Silpakorn University, Bangkok, 1992; I-r: Ambassador John McCarthy, Somporn Rodboon, curator Anne Kirker. A partnership with Queensland Art Gallery. 
For the touring exhibitions we frequently borrowed directly from artists, who were much more accepting of varying physical conditions for the display of their work than public and private collectors. The artists wanted their work to be seen and we made a point always of sending them a detailed report of their show's tour, including press coverage. Despite the varying physical conditions, Asialink made only two insurance claims: ${ }^{15}$ a remarkable record considering that an Asialink-sponsored exhibition opened in the region every 23 days over those 20 years. ${ }^{16}$

The 'Background Notes' that were prepared in 1991 as guidance for possible curators are both telling in their practicality and, 20 years later, in their surprising relevance. They assert that the exhibition had to be sensitive to the audience, aware of the context, and aware of constraints, including costs, hardiness of the travelling works and physical limits of the host venues. They also outline the importance of the travelling curator as the representative of the exhibition, the need for the curator to be flexible and 'able to "go with the flow" when things go wrong', and for artists to be sensitive to the issue of the discrepancy between arts funding in Asia and Australia: 'Australia's funding for artists is sometimes seen as lavish' ${ }^{17}$

\section{Key Principles for the Program over 20 Years}

The success of the Asialink Arts Program was based on the active implementation of several principles: a focus on quality programs, openness to new ideas and ventures, working in partnership, establishing excellent personal networks, and adding value to existing programs and arrangements.

The credibility of the Asialink program within the arts community was essential to its viability. The belief of arts practitioners in the quality of the program encouraged their involvement and also promoted the interest of good staff in the organisation and the development of stable partnerships. The quality of the program, in turn, led to positive and active press and public interest in Asialink's work. An instance of this was the Sun Gazing exhibition program in Japan of 2002-2004, which had an audience of nearly 300,000 people, and generated over 200 print media stories. It included Patricia Piccinini; We are

\footnotetext{
15 One, for wilful damage to a silver bowl in Vietnam; and another, for a dropped crate at Mumbai airport, resulting in a broken glass artwork.

16 The title of the book on the exhibition program, Every 23 Days, was based on the number of exhibition openings that had occurred over the 20-year period, which averaged out as 'every 23 days'.

17 Carroll, 'Some Background Notes for Curators and Artists Interested in the Asialink Exhibition Program' (Asialink, University of Melbourne, 1991).
} 
Family which broke attendance records at the Hara Museum of Contemporary Art in Tokyo, with people queuing to get in, and there was standing-room only for the artist's lecture at the Tokyo National University of Fine Arts. ${ }^{18}$

Active and interested advisory committees of key people from around Australia contributed to and oversaw the program. Artists, curators, theatre practitioners, writers, arts managers, funders and musicians, male and female, of every age, kept Asialink focused on its mission. One important and always valuable criterion of Australia Council support was the inclusion of at least one person of Asian-Australian background on each Asialink advisory committee. Rather than being tokenistic, this inclusion maintained a focus on the central issue of Asialink's engagement.

DFAT and the Australia Council, as the two main funders of the program, had different agendas: the first was to support the political and economic interests of the country, and the second to support the interests of the arts community. For an arts program like Asialink's, these goals were sometimes at odds. An exhibition on golf, for example, might conform to the diplomatic interests of DFAT, but not of the arts community and, one of interest to the arts community on, for example, sexuality - an issue within those Asian countries that were predominantly Islamic - might be an issue for DFAT. Asialink's response was that some 80 per cent of the arts activity in Australia dealt with issues of pertinence and relevance between these two extremes and it was those issues that we explored. Asialink was sensitive to the criticism that its existence was based on its political and business value to DFAT and we were concerned to stress that if a program did not have value to the arts community it would not be viable.

From the beginning we looked outwards, trying to draw the ideas, projects, know-how, resources and funds of others into our work. It was clear from the outset that Asialink did not have the resources to undertake the work without relying on partnerships. Bringing in partners with their own support systems to add value to the project meant vastly increasing what was available and expanding the number of people in Australia with knowledge, contacts and interest to do the 'next' program themselves. The value of these partnerships was made starkly evident in the contrast between the internal budgets of Asialink and holistic budgets of the total projects. The Sun Gazing visual arts program with Japan saw the the base income of $\$ 500,000$ quadrupled by income from our partners. While this is a literal way to 'value' a partnership, the financial support does translate as real commitment by all involved. ${ }^{19}$

18 See Carroll, Sun Gazing; The Australia-Japan Art Exhibitions Touring Program 2002-04 (Asialink, University of Melbourne, 2005), 3, 18.

19 And vice versa. There were times when we regretted not achieving more support from international partners, seeing this commitment as commensurate with the commitment to the total project idea. 
Asialink had to raise all its funds (and so, contrary to popular opinion, was not in a position to act as a funding body for the projects of other people). To be involved, Asialink had to add to a project a mixture of our capacity, our knowledge, our experience, and our work. Practically the program was run as leanly as possible. People were often surprised that the program did as much as it did with an arts staff of up to five people.

\section{The Asialink Residency Program}

The VACB had established the idea of a residency program in Asia in the late 1980s. True to the idea that it takes networks and commitment to get a program like this going, and despite attempting to make contact with relevant individuals and organisations in Asia, the VACB did not have the staff to follow up on its early plans. By 1990 only one artist, Joan Grounds, had travelled on the VACB program and David Castle was soon to follow. As a result of our approach to the VACB, it was agreed that Asialink would take over the residency program, in conjunction with funding for touring exhibitions.

When Asialink first mooted the idea to potential hosts of Australian artists coming to live and work in Asia, it was met with some trepidation. The idea of residencies was unfamiliar and there was concern over the cultural and language difficulties that may arise. Initially, universities, which were more accustomed to foreign engagement, were the first to agree to act as hosts. Kookmin University in South Korea, Silpakorn University in Thailand and the Jakarta Arts Institute in Indonesia were among the first to come on board. As the program continued, confidence grew and the idea of residencies became more acceptable. Gradually the arts bureaucracies in various governments started to create their own residency programs, such as Taipei Artist Village and, more recently, Tokyo Wonder Site.

From the end of 1991, when four people were scheduled to take up residencies, the program grew to 40 each year. In 2004, the arts program published a booklet on the residencies that listed all the residents to that date. The first edition was titled 35,000 Days in Asia, the second, in 2007, amended to 45,000 Days in Asia, reflecting the increasing number of residencies. By 2010 there had been over 600 Australians working for up to four months in the field, across 18 countries, with over 300 hosts. 


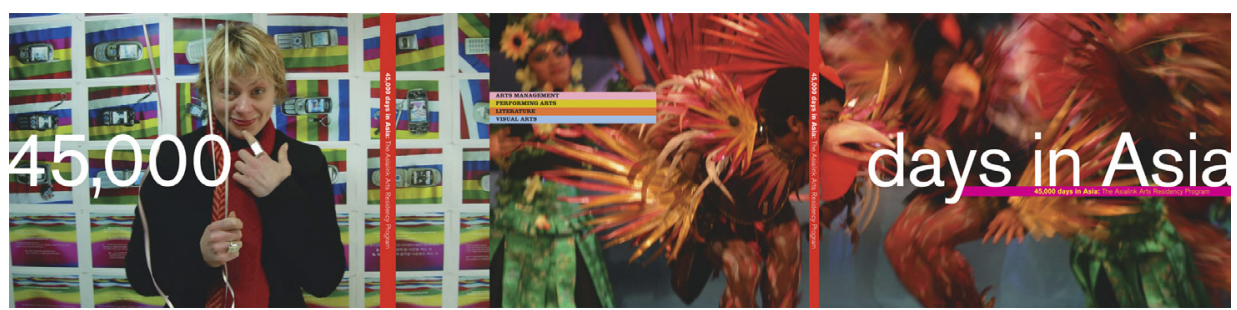

\section{Cover of publication: 45,000 Days in Asia, the Asialink Residency Program, 2007.}

Design: Lin Tobias, LaBella Design; image courtesy of Asialink, University of Melbourne

The VACB has an international network of rented studios - of 'bricks \& mortar' spaces. There is currently one studio in Asia, in Tokyo. Asialink worked on a slightly different premise: that a local host provided help securing working space and accommodation and, in return, had access to a 'foreign' artist in whatever way was of mutual benefit. This process was less secure than the studio model, but it meant there were immediate local contacts for the artist. It also meant that if something was not going well, we could change hosts the following year, and we could also respond to the interests of Australians. For example, Kookmin was a design/craft focused host, but it was clear that there was a lot of interest in Australia in other areas of work in Korea. Ssamzie Space, with its cutting edge, youth-focused new media scene proved very popular, and we were able to adapt the program to provide access to it. ${ }^{20}$

The residency program started with visual arts, then added performing arts and literature. An important fourth program was for arts managers, an initiative led by then chair of Asialink, Carrillo Gantner, and then head of the Ford Foundation's arts program in Jakarta, Jennifer Lindsay. Their logic was that, by introducing arts managers from Australia to regional networks, those networks would go on to develop new programs themselves - which is what happened. It also created stronger links in the then fledgling area of arts management in Asia, with the Australians frequently providing management support to new ventures there.

20 This example, in Seoul, is indicative of the fluid nature of institutions and organisations in Asia. Kookmin University enjoys the high respect that is common for an educational institution in a Confucian society, and our links there proved of great benefit to Asialink, through the establishment of a new Korea Program in the mid-1990s, including three exhibitions of Australian art and craft at the Seoul Arts Center in 1996. Many important Australian artists, like Carlier Makigawa, went to Kookmin and made links back into Australia. When you are starting a new program, you look back with great gratitude to the people who first accepted your overtures. Kookmin is among these. Ssamzie Space was set up as a privately supported venue for young artists to work and exhibit. It was in an area of Seoul near universities, bars, galleries and generally a 'hot' scene. Australian artists loved it, and many connections were made through their stays there. The initiating director, Kim Hong Hee, went on to work in various public art galleries and, in 2013, is the Director of the Seoul Museum of Art. Her connections to Australia have been long and very strong. 


\section{Second-Stage Programs}

Each of the four 'art form' areas, including arts management, developed what we called 'second-stage' areas of action.

\section{Arts Management}

Extensions of the arts management program included internships, development of arts management how-to booklets, tours and teaching. The internship program that brought Indonesian arts managers to Australia was supported by the Ford Foundation in Jakarta. The experiences of the Indonesian participants over a ten-year period were recorded in the Asialink booklet Jalan Jalan. ${ }^{21}$ The program was further extended with the creation of the Northern Territory/Nusa Tenggara Timur (NT/NTT) program, which enabled Territorians and the people of Eastern Indonesia to work together on various capacity-building projects. The manuals that were developed for Indonesian practitioners addressed issues of exhibition touring, event management and community cultural development practice. The booklets were translated into Indonesian and distributed there. ${ }^{22}$

Asialink had been the organiser of a number of short tours for arts managers from Asia to Australia, combining visits and lectures with workshop activity. An extension of this was Australian arts managers teaching at various seminars in the region - including on topics such as lighting, marketing, promotion, and curatorial practice. The majority of Asialink staff also gave talks and lectures in tertiary institutions in Australia about working in Asia, either to curatorial students, arts managers or artists. The core message of these presentations was the necessity of thinking a little differently when working in Asia than one might in Australia.

\footnotetext{
21 Georgia Sedgwick, Jalan-Jalan: The Indonesia-Australia Arts Management Program 1999-2006 (Asialink, University of Melbourne, 2006).

22 The three booklets were: Pameran Keliling; Sebuah Panduan Praktis untuk Galeri dan Museum Seni Indonesia (Asialink, University of Melbourne \& NETS Victoria, 2010); an edited version of Sara Kelly, Travelling Exhibitions, A Practical Handbook for Metropolitan and Regional Galleries and Museums (NETS Victoria, 1994), which was translated into Indonesian and with an introduction by Wulan Dirgantoro, School of Asian Languages and Studies, University of Tasmania; Panduan Pengembangan Budaya Masyarakat (Arts and Community Development) (Asialink, University of Melbourne and CCDNSW), Victoria Keighery, Director, Community Cultural Development, NSW, 2010, with support from Kate Ben-Tovim, Arts Manager in Residence, Yayasan Bagong Kussudiardjo, Yogyakarta, 2009, translated and with an introduction by Jeannie Park, Director, YBK, Yogyakarta; and Perencanaan dan Pengelolaan Event dan Festival, Asialink, University of Melbourne and UTS, an edited version of Rob Harris and Johnny Allen, eds, Regional Event Management, Australian Centre for Event Management, University of Technology, NSW 2002, translated and with an introduction by Amna Kusumo, Director, Yayasan Kelola, Jakarta, 2010. The three booklets were printed in runs of 5000 (as well as being available online) and all were distributed through Yayasan Kelola within one week.
} 


\section{Literature}

The main second-stage program in literature was also a touring program. Adapted from the exhibition touring idea, then literature manager, Amanda Lawrence, devised an ambitious and successful touring program for our leading writers. With support from the Australia Council and DFAT, she initiated and managed intensive tours of up to two weeks' duration to China, India, Korea, Japan and Singapore, often focusing on a book fair, and including readings at bookshops, universities, schools and wide ranging discussions with the local literary community. Peter Carey, Tim Winton, Kate Grenville, Alex Miller, Kim Scott, Sonia Hartnett and Geraldine Brooks are among the Australian writers who took part. Brooks had just won the Pulitzer Prize for Fiction in 2006 when she put her planned Asialink trip to China ahead of all others. As a consequence of these tours, rights were sold, books bought, conversations had and, generally, the profile of Australian literature was raised as never before. The program addressed an evident need - the Asialink stand at the Beijing book fair, which was shared with Austrade, was the only stand representing Australian literature and publishing in a total of 45 countries throughout Europe and America.

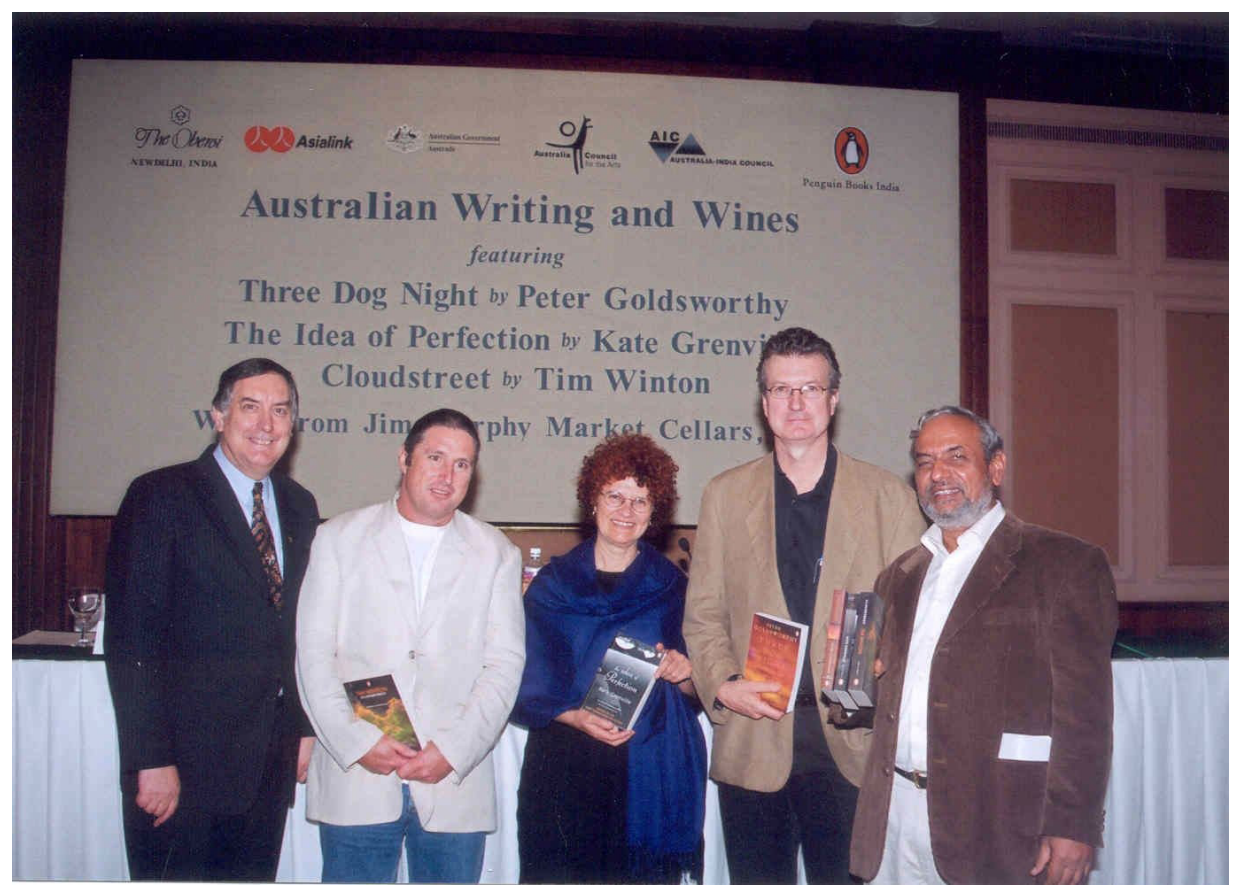

Asialink Touring Writers Program, presentation to three Australian writers; second from left: Tim Winton, Kate Grenville and Peter Goldsworthy, with other official guests, Oberoi Hotel, New Delhi, 2004.

Photographer unknown; image courtesy of Asialink, University of Melbourne 
Concurrent with these tours were writers events of both Australian authors with interests in Asia as well as writers from Asia, which became a key part of Asialink's public program in Australia, mostly in Melbourne, but also at writers festivals in other states. The 'nights of stories' program, which was always popular, evolved into a Winter Writers Series. Visitors included well-known authors, such as Vikram Seth, who spoke to 500-strong audiences.

\section{Performing Arts and Cross Media}

A true 'second-stage' program was Swimming with the Tide, which asked for ideas from the field of community arts practice, mostly under the performing arts rubric. A small steering committee selected projects for work in Indonesia, which included theatre development in Sulawesi, performance in Java and Sydney, and politically inspired work in Jakarta's factories. ${ }^{23}$ A second program in performing arts, which had a similar practice to Swimming with the Tide was Neon Rising: Asialink Japan Dance Exchange. Five collaborative projects were involved, with practitioners from around Australia working with Japanese colleagues to develop a wide range of programs that were shown in both countries. ${ }^{24}$

As a result of the increasingly cross-media practice of artists throughout the region, Asialink sought to be flexible in its programs in a way that would support artists operating outside the separate practice areas. An important annual forum was held for the first time in 2004 and focused on this area, bringing speakers from around the region to join Australian colleagues in vigorous discussion.

\section{Visual Arts}

Visual arts stands apart from the 'second-stage' programs as it was a core area from the beginning. It too, however, had components that can be discussed separately: exhibition touring, South-East Asian collaborations, and programs relating to South Asia, Korea and Japan.

Exhibition touring was the bedrock of the program, strongly supported by funders in Australia as well as partner galleries, institutions and individuals both in Australia and throughout the region. Exhibition touring began with a focus on the 'non- Foundation/Council \& Institute countries', that is, those in

\footnotetext{
23 Zoe Dawkins, ed., Swimming with the Tide; Australia-Indonesia Arts \& Community Program (Asialink, University of Melbourne, 2004). The committee was Robin Laurie, Andrew Donovan, Bernice Gerrand, Julia Tymukas and Alison Carroll. The introduction was by Bernice Gerrand, manager, Community Cultural Development Board, Australia Council, and the projects were: Green Turtle Dreaming, Beyond the Factory Walls, Crocodile Hotel, West Sumatran Textile Workshop, and Girt by Sea.

24 Swee Lim, Neon Rising; Asialink Japan Dance Exchange (Asialink, University of Melbourne, 2007). Australian dance artists and organisations included Jo Lloyd, Sue Healey and Co, Kage, Leigh Warren and Dancers, and De Quincey Co, all working with Japanese colleagues.
} 
Asia without an associated DFAT funding organisation, such as the AustraliaJapan Foundation (AJF) or the Australia India Council. So, the emphasis was on South-East Asia (excluding Indonesia) and the smaller countries of South Asia. Generally these exhibitons have been Australian shows touring to a number of venues in the region.

The South-East Asian collaborations grew out of the early touring shows. They included Rapport, devised by two Australian and Singaporean curators, and representing four artists from each country, which then toured to both; Saisampan, of four Australian and four Thai artists, curated by a Thai curator and site-specific to Chiang Mai; Kawing, involving four Northern Territory artists travelling to four regional venues in the Philippines and making work there; and, Patterning, in which a core of Australian work responding to the idea of patterns was 'answered' by local work in Pakistan, the Philippines and Indonesia. A further extension was Foundations of Gold, in which one artist from five Asian cities came to Melbourne to work with an Australian partner to produce new work, based on gold, resulting in a show that toured to the six (including Melbourne) cities. A more recent example was Run Artist Run, of work provided by artist-run initiatives in Australia, Singapore and Vietnam. These projects were more complicated to organise than traditional touring shows, but the results were frequently effective in engagement and reward. ${ }^{25}$

Work in South Asia led to the major show Fire and Life, which included five Australian and five Indian artists working together in each of their cities in Australia and India, with ten individual shows being the outcome. ${ }^{26}$

25 Rapport: Eight Artists from Singapore and Australia, curators Natalie King and Tay Swee-Lin; artists Hany Armanious, Carolyn Eskdale, Christopher Langton, Nicola Loder, Amanda Heng, Salleh Japar, Baet Yeok Kuan and Matthew Ngui; partners Monash University Gallery, Singapore Art Museum; tour Singapore, Melbourne, Canberra, Brisbane, 1996-1997; Saisampan: Soul Ties-Australian and Thai Artists in Collaboration, curator Somporn Rodboon; artists Chaiyot Chandratita, Peerapong Duangkaew, Joan Grounds, David Jensz, Noelene Lucas, Bannarak Nakbanlang, Araya Rasdjarmrearnsook and Wendy Teakel; partner Chiang Mai University, tour Chiang Mai, 2002; Kawing: Four Regional Philippines Exhibitions, curator Cath Bowdler; artists Dennis Bezzant, Jacki Fleet, Winsome Jobling and Techy Masero; partner 24 Hour Art, Northern Territory Centre for Contemporary Art; tour Manila, Davao, Baguio, Cebu, Negros, Puerto Princesa, Darwin, 2001-2002; Patterning: In Contemporary Art, Layers of Meaning, curator Merryn Gates; Australian artists Vivienne Binns, Fassih Keiso, Damon Moon and Stephen Goldate, Munupi Arts and Craft Association, David Sequeira, Jaishree Srinivasan, Wilma Tobacco and Sara Thorn; partner Canberra School of Art Gallery; tour Manila, Lahore, Canberra, Yogyakarta, Ubud, Bandung, Jakarta, 1997-1998; Foundations of Gold, curators Alison Carroll, Suzanne Davies, Beatrice Schlabowsky; artists Georgia Chapman, Eugene Chua GinMinn, Brenda V. Fajardo, Kim Ki-ra, Makiko Mitsunari, Pamela Stadus, Blanche Tilden and Caroline Williams; partners City of Melbourne, RMIT Gallery; tour Melbourne, Mumbai, Manila, Seoul, Osaka, Singapore, 2001-2002; Run Artist Run, curators Katie Lee and Dean Linguey, Mark Feary, David Teh, with Sarah Bond; artists Damiano Bertoli, Sue Dodd and Bianca Hester, Katie Lee and Dean Linguey, Ruark Lewis and Jonathon Jones; partners 1/2 doz., a little blah blah, Conical Inc., p-10, Plastique Kinetic Worms, Ryllega; tour Melbourne, Hanoi, Ho Chi Minh City, Singapore, 2007.

26 Fire and Life, curators Julie Ewington, Victoria Lynn, Chaitanya Sambrani and Alison Carroll; artists Jon Cattapan, David Jensz, Joan Grounds, Derek Kreckler, Judith Wright, N.S. Harsha, Surendran Nair, Jayashree Chakravarty, N.N. Rimson, Pushpamala; tour Bangalore, Baroda, Calcutta, Delhi, Mumbai, Melbourne, Sydney, Brisbane, Canberra, Perth, 1996-1997. 
This, combined with our strong presence at the Bangladesh Biennale and specially prepared projects at smaller venues in Pakistan and Sri Lanka, confirmed our interest in the region.

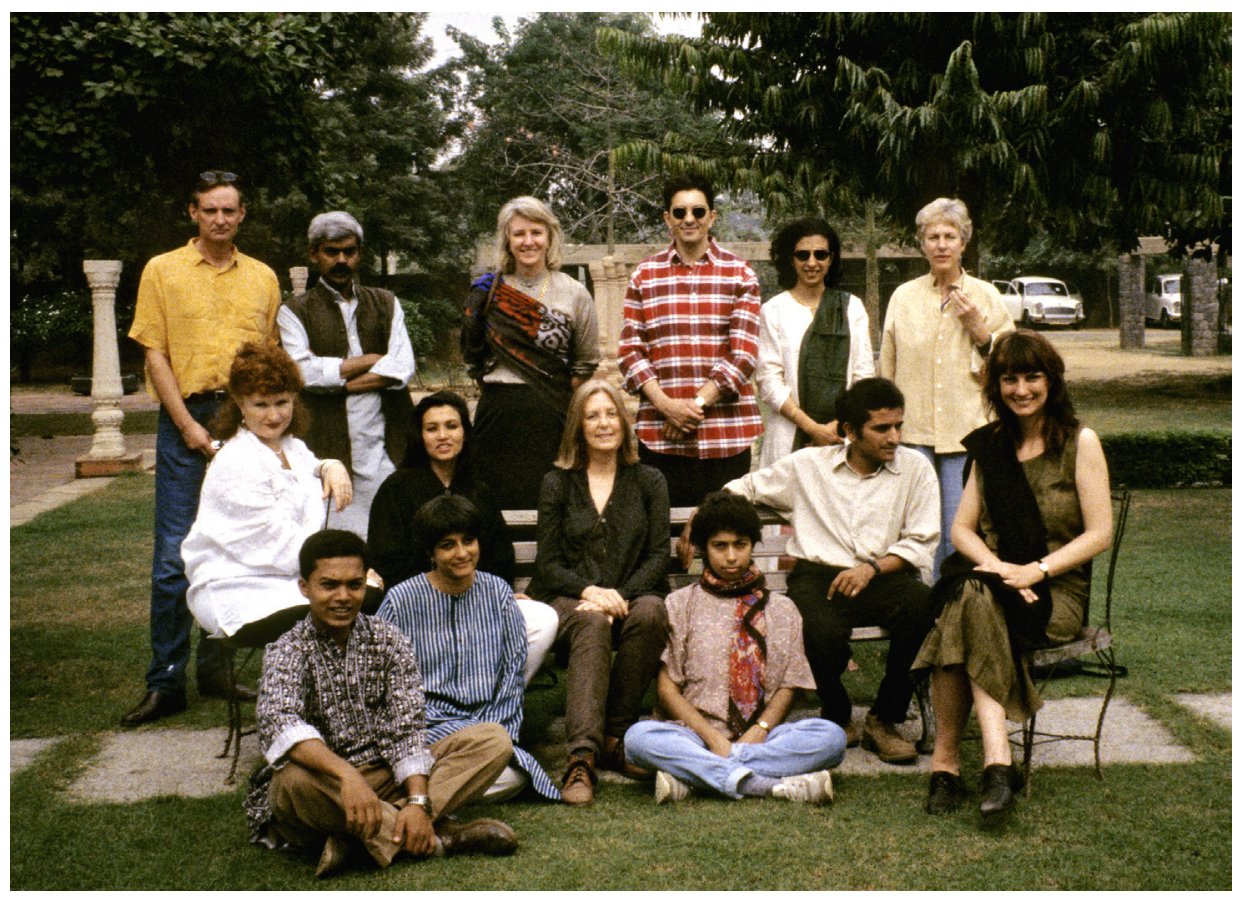

'Fire and Life' 1996-1997; I-r, top: artists and curators, Derek Kreckler, Surendran Nair, Alison Carroll, Jon Cattapan, Shireen Gandhi, Joan Grounds; middle: Julie Ewington, Suhanya Raffel, Judith Wright, N.S. Harsha, Victoria Lynn; seated on ground: Chaitanya Sambrani, Pushpamala N. and Jayshree Chakravarty, at Sanskriti Kendra, New Delhi, for exhibition 'Fire and Life', of ten exhibitions in India and Australia by five pairs of artists from both countries.

Photographer unknown; image courtesy of Asialink, University of Melbourne

The Korea program developed out of our wish to acknowledge the work occurring outside South and South-East Asia. Four Korean curators were invited to come to Australia and, out of this visit, seven visual arts projects followed in the mid-1990s, including a combined exhibition of Aboriginal art, craft and design, and general visual arts at the Seoul Arts Center in 1996. An exchange with Art Sonje saw contemporary Korean art come to the National Gallery of Victoria and the Art Gallery of New South Wales for the first time. ${ }^{27}$

27 The three exhibitions at Seoul Arts Center were Australia: Familiar and Strange, curator Timothy Morrell, Voices of the Earth, curator Gabrielle Pizzi; and, Aurora: Australian Wood Metal Glass Fibre Ceramics, curators Suzanne Davies, Grant Hannan, Ray Stebbins and Rachel Young. The Slowness of Speed - Contemporary Korean Art, shown in Melbourne and Sydney, was curated by Kim Sun Jung, Director of Art Sonje, Seoul. 


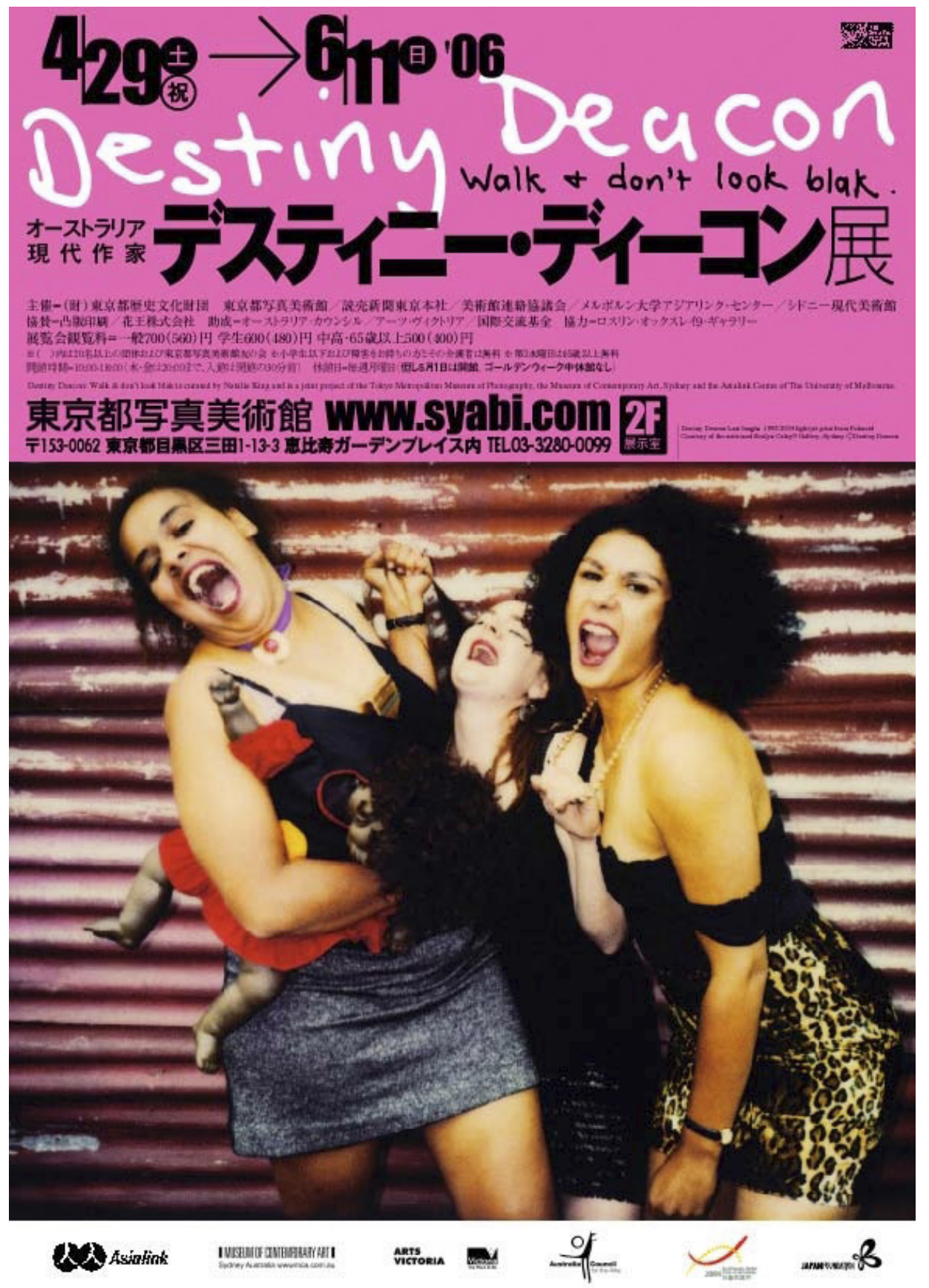

Poster from exhibition at Tokyo Metropolitan Museum of Photography, Tokyo, 'Destiny Deacon; Walk \& Don't Look Blak' 2006.

Design: Tokyo Metropolitan Museum of Photography; image courtesy of Asialink, University of Melbourne 
The Japan program grew out of the success of our engagement with Korea. Asialink's initial project was to lead a tour of visual arts curators in the late 1990s to Japan. As a result, the AJF and Australia Council supported a threeyear program running from 2002-2004 which fostered establishing relationships in Japan with museums that were willing to host Australian art. The second iteration, running from 2005-2009, was more collaborative and involved cocurated exhibitions of Australian and Japanese work being shown in both countries. These programs also encompassed curatorial visits and two important symposia in Tokyo and Sydney. ${ }^{28}$ An outcome has been the ongoing Utopia@ Asialink itinerant visual arts project.

\section{Advocacy}

In terms of advocacy for Asia-Australia arts engagement, Asialink focused on forums, publications and speaking at international events about elements of our mission, our program and our thinking. The annual Arts Forum, which started as a half-day engagement in Melbourne for the Asialink committee members representing the three art forms, evolved into a full-day public event that hosted speakers from throughout Asia. This was a highlight of the year, focusing on special issues, of community arts, residencies, and cross-cultural collaborations, and on the arts of specific countries: China, Japan, Korea and Indonesia. The arts program produced catalogues for each exhibition plus special publications on programs alluded to here, which were designed to alert local audiences to Asialink's overseas activities. The yearly Newsletter listed all the residents for that year. Asialinks arts staff were also required to contribute at least one article on their work to an external publication.

\section{Challenges}

There are many measurable success stories for Asialink Arts. The high (and competitive ${ }^{29}$ ) level of both individual and institutional engagement from Australia in Asialink's arts program has led to a wide dissemination of information and experience through this sector in Australia. This experience has been valued extremely highly by participants. ${ }^{30}$ Asialink maintains that

\footnotetext{
28 'The Tokyo Forum 2006' and 'The Sydney Forum 2008'; see http://asialink.unimelb.edu.au/_data/assets/ pdf_file/0006/421872/Asialink_SunWalking.pdf Asialink published two booklets reporting on the programs: Sun Gazing; the Australia-Japan Art Exhibitions Touring Program 2002-04, and Sun Walking; Australia-Japan Visual Arts Partnerships Program 2005-9 (2009). The second volume was in English and Japanese.

29 One in ten applications for residencies were successful (based on financial capacity, not the quality of the applications), and advertised programs in other areas were always over-subscribed.

30 The 2005 survey of past residents revealed that 61 per cent of respondents found their experience 'extremely influential' to their practice, 25 per cent 'very influential', and only four per cent of 'moderate or of limited influence'. In the same survey, 68 per cent of respondents had undertaken follow-up projects (from Asialink files).
} 
audience numbers in Asia, despite figures being hard to confirm, especially for projects with no entrance fee, have been higher for Asialink exhibitions than for any other Australian cultural program internationally. The figures noted for the Japan programs - where there are entrance fees and therefore statisticsof 300,000 for the 2005-2009 program are testament to audience hunger for such projects. The thousands of media reports in print, radio, television and through new media channels have always been greater than for similar events in Australia.

And yet, Asialink Arts, as the figures at the beginning of this chapter attest, has never had large support from any source. It was this writer's ongoing concern that there were no 'core' funds from anywhere for salaries or projects. All staff were on one-year contracts, dependent on that year's success, or not, with grant applications. This situation resulted from two main issues: the arts sector's general struggle for support, especially for offshore and avant-garde projects like ours, and for projects related to 'Asia'.

Over 20 years the general response to 'engagement with Asia' has hardly shifted. There has been wide agreement that 'Asia' is important, but the action to support engagement has been either just adequate (as in our case) or worse. As the saying goes, 'people talk the talk, but don't walk the walk'. It is well known in Australia that the number of students of Asian languages at both secondary and tertiary level has fallen over the last ten years. ${ }^{31}$ The Currency House Policy Paper Finding a Place on the Asian Stage (2012), notes that no tertiary arts instituion in Australia offers core teaching of Asian performing arts practice. It notes the general fall in funding by the Australia Council for performing arts projects in Asia as a percentage of international engagement from around 50 per cent in the early 1990s to less than 20 per cent by $2010 .^{32}$

This essay has outlined how Asialink Arts, a small program evolving in Melbourne from 1990, became the main arts exchange vehicle for Australian arts engagement with Asia over the next two decades and that a critical component of the exchange, as I have argued, was in forging cross-cultural dialogue. It was about more than government or business priorities. It was about experiencing something that you could 'never have been told what it would be like', and it being 'the hardest and the best thing' you have ever done. I wish this opportunity was available for us all.

\footnotetext{
31 Australia in the Asian Century (168) notes 'less than 6 per cent of Australian school students studied Indonesian, Japanese, Korean or Chinese (Mandarin) in Year 12 ... Fewer Year 12 students studied Indonesian in 2009 than in 1972' and Japanese language student numbers 'fell by 16 per cent from 2000 to 2008'.

32 Finding a Place on the Asian Stage, 49-53, 24-25. These figures exclude the main museums of Australia, which get funding through different sources. Many, particularly QAG and, later, QAGOMA, have been very successful in a large number of important projects with Asian countries over this period.
} 


\section{A Postscript: 2013}

The arts sector in Asia in the 20 years to 2010 developed exponentially. At the beginning of the 1990s, Australia was in a position to be a leader in the region, with arts training, models for engagement and various cultural developments, but this changed. Many cities in Asia have developed dynamic cultural centres, activities, and international engagements, increasingly importantly, within the Asian region. What is the next step that Australia can take to be part of this, to build on all the connections made over the last 20 years, and to do so strategically and with strong government backing?

Asian expert Carrillo Gantner and I have put forward the idea of an Australian international cultural agency that has the functions of creating and managing a strategic national overview, linking programs to national priorities and the national interest, establishing funding priorities, developing programs, promoting Australia internationally, and recruiting cultural staff for overseas posts. ${ }^{33}$ Working in Asia, and extending Asialink's work onto another, stronger level, would be central to this. The arguments made against this are, first, costto which we say anything that is cost-effective should be a priority; second, that Australia has too small a population for such a special agency - to which we say many countries that are much smaller than Australia have very effective international bodies ${ }^{34}$ and, third, that it is unnecessary change - to which we reply that change is needed. This is a new model that should be addressed now.

33 Finding a Place on the Asian Stage, 58-59.

34 The Dutch, Swiss and Scandinavia, for example; an alternative comparison is Britain, with three times Australia's population, spending more than three times our international arts budget. 
This text taken from Contemporary Asian Art and Exhibitions: Connectivities and world-making, by Michelle Antoinette and Caroline Turner, published 2014 by ANU Press, The Australian National University, Canberra, Australia. 